\title{
Penerapan Strategi Actually, Intelectually, and Repetition untuk Meningkatkan Minat dan Hasil Belajar Sejarah Siswa Kelas 5 Sekolah Dasar
}

\author{
Supartini \\ SDN 3 Mlopoharjo \\ supartiniumi65@gmail.com
}

\section{Article History}

accepted 01/06/2020

\begin{abstract}
The objectives of this Classroom Action Research are to improve: (1) The learning process by applying the AIR type learning strategy (Auditory, Intellectualy, and Repetition) in the material from the history of the Hindu, Buddhist and Islamic periods in Indonesia in grade V SDN 3 Mlopoharjo, Wuryantoro in the school year 2018/2019. (2) Students' learning interest, after implementing the AIR type learning strategy (Auditory, Intellectualy, and Repetition) in the material from the historical heritage of the Hindu, Buddhist and Islamic periods in Indonesia in grade V SDN 3 Mlopoharjo, Wuryantoro in the 2018/2019 academic year. (3) Learning outcomes in material relics of the history of Hinduism, Buddhism and Islam in Indonesia in material from the history of the Hindu, Buddhist and Islamic periods in Indonesia after implementing the AIR type learning strategy (Auditory, Intellectualy, and Repetition)

In accordance with the objectives, this study uses the classroom action method by applying the AIR type learning strategy (Auditory, Intellectualy, and Repetition) in the material from the historical heritage of the Hindu, Buddhist and Islamic periods in Indonesia. The subjects of this study were students of class V SDN 3 Mlopoharjo, Wuryantoro in the 2018/2019 academic year, totaling 4 students, consisting of 3 male students and 1 female student.

Data collection techniques carried out include: observation or observation, interviews, document review, field notes, and tests. This classroom action research resulted in the following conclusions: (1) There was an increase in learning from teacher centered to student centered. (2) There is an increase in students' interest in learning from pre-cycle $25 \%$, cycle I $75 \%$, cycle II $100 \%$. (3) There is an increase in student learning outcomes from pre-cycle $25 \%$, cycle II $50 \%$ and cycle II $75 \%$.
\end{abstract}

Keywords: AIR type learning strategies, interests, and learning outcomes

\begin{abstract}
Abstrak
Tujuan Penelitian Tindakan Kelas ini adalah untuk meningkatkan : (1) Proses pembelajaran dengan menerapkan strategi pembelajaran tipe AIR ( Auditory, Intellectualy, and Repetition ) dalam materi peninggalan sejarah masa Hindu, Budha dan Islam di Indonesia pada kelas $\mathrm{V}$ SDN 3 Mlopoharjo, Wuryantoro tahun pelajaran 2018/2019. (2) Minat belajar siswa, setelah diterapkan strategi pembelajaran tipe AIR ( Auditory, Intellectualy, and Repetition ) dalam materi peninggalan sejarah masa Hindu, Budha dan Islam di Indonesia pada kelas V SDN 3 Mlopoharjo, Wuryantoro tahun pelajaran 2018/2019. (3) Hasil belajar dalam materi peninggalan sejarah masa Hindu, Budha dan Islam di Indonesia dalam materi peninggalan sejarah masa Hindu, Budha dan Islam di Indonesia setelah diterapkan strategi pembelajaran tipe AIR ( Auditory, Intellectualy, and Repetition ) Sesuai dengan tujuan, maka penelitian ini menggunakan metode tindakan kelas dengan menerapkan strategi pembelajaran tipe AIR (Auditory, Intellectualy, and Repetition ) dalam materi peninggalan sejarah masa Hindu, Budha dan Islam di Indonesia. Subyek penelitian ini adalah siswa kelas V SDN 3 Mlopoharjo, Wuryantoro tahun pelajaran 2018/2019 yang berjumlah 4 siswa, terdiri dari 3 siswa laki-laki dan 1 siswa perempuan. Teknik pengumpulan data yang dilaksanakan meliputi: pengamatan atau observasi, wawancara, kajian dokumen, catatan lapangan, dan tes. Penelitian tindakan kelas ini menghasilkan simpulan sebagai berikut : (1) Ada peningkatan pembelajaran dari teacher centered menjadi student centered. (2) Ada peningkatan minat belajar siswa dari prasiklus $25 \%$,
\end{abstract}


siklus I 75\%, siklus II 100\%. (3) Ada peningkatan hasil belajar siswa dari prasiklus 25\%, siklus II $50 \%$ dan siklus II $75 \%$.

Kata kunci: strategi pembelajaran tipe AIR, minat, dan hasil belajar 


\section{PENDAHULUAN}

Kurikulum Tingkat Satuan Pendidikan ( KTSP ) Sekolah Dasar Negeri 3 Mlopoharjo, tahun Pelajaran 2018 / 2019 khususnya kelas V mata pelajaran IImu Pengetahuan Sosial ( IPS ) memuat 3 ( tiga ) jam pelajaran per minggu, yang meliputi 5 ( lima ) Kompetensi Dasar pada semester 1 dan 4 ( empat) Kompetensi dasar pada semester 2. Dengan muatan materi yang sangat banyak tersebut menjadikan pembelajaran terkesan hanya mengejar pemenuhan materi. Siswa dituntut harus banyak membaca dan menghafal, yang kadang menjadi faktor pemicu kemalasan siswa.

Di samping materi yang sarat, saat pembelajaran yang berlangsung, guru masih menjadi centered of study dalam pembelajaran. Guru masih menjadi pusat belajar. Guru menjadi tokoh sentral. Siswa hanya sebagai pendengar yang duduk manis dan menjadi obyek pembelajaran. Metode ceramah diterapkan sepanjang pembelajaran meskipun sudah diselingi tanya jawab. Hal ini mengakibatkan siswa pasif, takut bergerak, takut bertanya, takut berpendapat. Pembelajaran berlangsung sangat "tertib" dan "tenang".

Perkembangan teknologi informasi dan komunikasi juga menjadi faktor yang sangat mempengaruhi siswa dalam belajar. Pengaruh gadget dan smartphone tidak hanya pada siswa perkotaan, tetapi juga merambah pada siswa di pedesaan, termasuk siswa - siswa di SD N 3 Mlpoharjo. Penggunaan gadget yang hanya untuk game mengakibatkan anak malas belajar, apalagi menghafal materi - materi tertentu. Saat di rumah, dengan waktu yang sangat banyak, siswa semakin asik dengan permainan di handphone.

Penelitian ini penting dilakukan mengingat langkah-langkah dalam strategi pembelajaran tipe Actually, Intelectually, and Repetition dengan dikolaborasi media kartu sejarah menurut peneliti tepat diterapkan dalam pembelajaran dengan materi sejarah. Strategi pembelajaran ini akan mengajak siswa untuk melatih pendengaran dan keberaniannya dalam berpendapat. Melatih untuk memecahkan masalah. Melatih mengingat kembali. Siswa lebih aktif dan kreatif.

Penerapan strategi pembelajaran kooperatif yang menggunakan tipe Auditory, intellectually, repetitioan (AIR) pernah dilakukan oleh seorang mahasiswa dalam skripsinya. Dialah Irfi Hestu Nugraheni dari Fakultas Keguruan dan IImu Pendidikan, Universitas Sebelas Maret Surakarta.

Penggunaan strategi tersebut, dengan didukung media kartu domino, dapat meningkatkan kemampuan operasi hitung campuran bilangan bulat. Penerapan model pembelajaran tipe AIR dapat meningkatkan hasil belajar IPS di SDN 032 Kualu Peneliin laih juga dilakukan oleh Sabitriana Hutapea seorang mahasiswa di Universitas Medan. Simpulan pada penelitian ini adalah dengan menggunakan strategi pembelajaran kooperatif tipe AIR dapat meningkatkan hasil belajar persamaan kuadrat di kelas X.

Dengan memperoleh gambaran hasil penelitian di atas pelaksana penelitian berasumsi bahwa dengan menerapkan strategi pembelajaran kooperatif tipe AIR dapat meningkatkan hasil belajar siswa, yang tentunya dikolaborasi dengan media kartu sejarah, agar berhasil maksimal.

\section{METODE}

Artikel yang berasal dari penelitian tindakan kelas ini dilakukan selama 6 (enam) bulan, dimulai bulan Juli sampai dengan Desember 2018. Penelitian dilaksanakan di SDN 3 Mlopoharjo kecamatan Wuryantoro kabupaten Wonogiri, pada siswa kelas V semester I tahun pelajaran 2018 / 2019. Penentuan tempat tersebut mempertimbangkan beberapa hal, di antaranya :

Pelaksana penelitian adalah guru kelas V SDN 3 Mlopoharjo, sehingga memudahkan proses penelitian karena tidak meninggalkan tugas utama sebagai guru. 
Adanya kesesuaian antara model pembelajaran yang diterapkan guru dengan perkembamgan usia, fisik, mental siswa kelas $\mathrm{V}$ sekolah dasar.

Pelaksanaan penelitian sangat berpengaruh terhadap kesuksesan proses pembelajaran ke arah yang lebih baik.

Subyek penelitian adalah, siswa kelas V SDN 3 Mlopoharjo Kecamatan Wuryantoro pada semester I tahun pelajaran 2018 / 2019 sejumlah 4 (empat ) orang terdiri dari 3 ( tiga ) anak laki-laki dan 1 ( satu ) anak perempuan. Alasan penentuan subyek adalah karena para siswa merupakan anak didik yang diteliti. Materi pembelajaran IImu Pengetahuan Sosial ( IPS ) dengan Kompetensi dasar mengenal makna peninggalan-peninggalan sejarah berskala nasional dari masa Hindu, yang Budha, dan Islam di Indonesia, nilai rata-rata kelas berada di bawah KKM yang ditentukan. Hal inilah yang menjadikan problem yang harus segera diatasi, agar kegiatan pembelajaran berkualitas. Pembelajaran dipenuhi dengan minat anak yang tinggi sehingga akan dapat mencapai tujuan dan mencapai kriteria ketuntasan yang dipersyaratkan.

Deskripsi secara umum mengenai siswa kelas V SDN 3 Mlopoharjo adalah anak-anak yang tinggal di pedesaan. Desa Mlopoharjo yang mereka huni, terdiri dari dusun Putuksari, Pakem dan Jambe. Kebanyakan dari mereka suka melihat televisi, main handphone, dan kurang suka membaca.

Jiwa kemandirian siswa untuk belajar masih kurang, sehingga mempengaruhi hasil. Hal ini menimbulkan masalah dalam pembelajaran. Dengan latar belakang kondisi orang tua dengan ekonomi rendah, pendidikan rendah akan mempengaruhi kualitas belajar siswa. Akibatnya minat dab prestasi belajar relative rendah.

Obyek penelitian adalah minat dan hasil belajar siswa tentang mengenal makna peninggalan sejarah masa Hindu, budha dan Islam di Indonesia.Obyek penelitian ini diambil oleh pelaksana penelitian dari Kompetensi dasar mata pelajaran IImu Pengetahuan Sosial kelas V, yang terdapat dalam Kurikulum Tingkat Satuan Pendidikan ( KTSP ) SDN 3Mlopoharjo Kecamatan Wuryantoro, tahun pelajaran2018 / 2019.

Penelitian ini memperoleh data melalui tes, observasi, wawancara, catatan lapangan, dan dokumentasi.

a. Tes

Alat tes yang digunakan dalam penelitian ini meliputi tes unjuk kerja dan tes tertulis. Dalam tes unjuk kerja, siswa mempresentasikan hasil diskusi kelompok dengan media kartu sejarah. Kemudian dilaksanakan tes tertulis, untuk mengetahui seberapa jauh penguasaan konsep materi pelajaran. Tes tertulis dilaksanakan tiap siklus pada pertemuan ketiga.

b. Observasi

Observasi yang dimaksud dalam penelitian tindakan ini adalah kegiatan mengamati kemudian mencatat gejala-gejala yang muncul selama proses pengamatan. Dalam kegiatan ini yang diamati adalah kerjasama atau kerja kelompok dua orang untuk menyelesaikan masalah yang disampaikan. Apakah siswa bekerjasama dengan semangat, partisipatif dalam mengikuti pembelajaran. Instrumen dalam observasi yang digunakan berupa kriteria pencapaian indikator kinerja, yang berupa penskoran dengan rentang nilai skala $1-5$ untuk tiap aspek yang diamati

c. Catatan Lapangan

Catatan lapangan adalah catatan tertulis tentang apa yang didengar, dilihat, dialami. Semua kejadian yang terjadi saat kegiatan pembelajaran dicatat secara deskriptif. Catatan ini dimanfaatkan sebagai bahan refleksi terhadap proses penelitian.

Pada saat melakukan penelitian, guru mencatat berbagai hal yang dianggap penting untuk dijadikan data tambahan penelitian guna mendukung analisis data. Dalam Subiyantoro (2017:80) , catatan lapangan berupa gambaran umum untuk penjelasan dan penafsiran yang bisa mencakup kesan ataupun penafsiran 
subyektif. Deskripsi itu misalnya pembelajaran lebih baik, perilaku anak kurang perhatian, ada pertengkaran, dan lain-lain.

Catatan lapangan bisa diambil pada saat guru melakukan apersepsi, tanya jawab, pembagian kelompok, diskusi, mengerjakan tugas.

d. Wawancara

Wawancara dilakukan dengan beberapa peserta didik untuk mengetahui seberapa besar minat peserta didik dalam mempelajari materi sejarah peninggalan masa Hindu, Budha, dan Islam di Indonesia. Wawancara dilakukan sebelum penerapan strategi tipe AIR dan sesudah penerapan. Teknik ini dilakukan secara fleksibel dan kekeluargaan untuk menjaga agar subyek tidak takut atau ragu-ragu menjawab pertanyaan-pertanyaan.

e. Dokumentasi

Dokumentasi yang digunakan berupa Daftar Nilai yang diperoleh sebelum penerapan Strategi Tipe AIR dan sesudah penerapan pada materi sejarah peninggalan masa Hindu, Budha, dan Islam di Indonesia. Teknik dokumentasi juga dilakukan dengan pengambilan gambar kegiatan-kegiatan selama penelitian. Potopoto kegiatan terdiri dari poto sebelum penerapan strategi, selama proses penerapan strategi, poto wawancara, dan lain-lain.

Suatu informasi yang akan dijadikan data penelitian perlu diperiksa validitasnya sehingga data tersebut dapat dipertanggungjawabkan dan dapat dijadikan dasar yang kuat dalam menarik kesimpulan. Teknik validasi data dalam penelitian ini adalah triangulasi. Triangulasi adalah teknik pemeriksaan validitas data dengan memanfaatkan sarana di luar data itu untuk keperluan pengecekan atau pembandingan.

Instrumen yang dipakai dalam penelitian ini meliputi : Silabus, Rencana Pelaksanaan Pembelajaran (RPP), Lembar Kegiatan Siswa, Lembar Observasi proses pembelajaran, Lembar Observasi guru, dan Tes Formatif Analisis data merupakan bagian terpenting dalam suatu penelitian. Dengan menganalisis data yang diperoleh pada penelitian, dapat membantu memberikan solusi bagi pemecahan masalah yang muncul. Dalam penelitian ini pelaksana penelitian menggunakan teknik analisis deskriptif komparatif. Teknik ini digunakan dengan membandingkan nilai tes antarsiklus dan indicator kinerja.

Analisis data dilakukan sejak awal sampai akhir penelitian. Hal ini dilakukan melalui tiga tahap, yaitu reduksi data, paparan data, simpulan. Reduksi data adalah proses penyederhanan yang dilakukan melalui seleksi, pemfokusan, dan pengabtraksian data mentah menjadi informasi yang bermakna. Paparan data adalah proses penampilan data secara lebih sederhana dalam bentuk paparan.

\section{HASIL DAN PEMBAHASAN}

Hasil penelitian tindakan kelas yang dilakukan penulis meliputi : deskripsi Prasiklus, hasil penelitian siklus 1, hasil penelitian siklus 2.

Deskripsi Prasiklus

1. Proses Pembelajaran

Dalam deskripsi prasiklus proses pembelajaran pada kondisi awal sebelum penerapan strategi pembelajaran tipe Actualy, Intelectualy, Repetition. Guru hanya menggunakan metode penjelasan dan Tanya jawab dengan strategi pembelajaran diskusi kelompok. Pembelajaran terlihat kurang aktif, siswa kurang focus dan cenderung pasif. Hal ini disebabkan pembelajaran dari guru kurang menarik, antusisme kurang, siswa lebih banyak diam dan hanya menjadi pendengar yang baik. Kondisi tersebut dirangkum dalam table berikut: 
Tabel 1

Rekap Proses Pembelajaran Prasiklus

\begin{tabular}{|l|l|l|l|l|l|}
\hline \multirow{2}{*}{ No } & \multirow{2}{*}{ Indikator } & Ya & Tidak \\
\cline { 3 - 6 } & & $\mathrm{F}$ & $\%$ & $\mathrm{~F}$ & $\%$ \\
\hline 1. & Aktif & 1 & $25 \%$ & 3 & $75 \%$ \\
\hline 2. & Antusias & 1 & $25 \%$ & 3 & $75 \%$ \\
\hline 3. & Kondusif & 1 & $25 \%$ & 3 & $75 \%$ \\
\hline Rerata & 1 & $25 \%$ & 3 & $75 \%$ \\
\hline \multicolumn{5}{|l}{ Kategori } & Kurang \\
\hline
\end{tabular}

2. Minat Belajar

Minat belajar siswa dapat diamati dari ketertarikan, perasaan senang, perhatian, dan semangat mengikuti pembelajaran. Pada kondisi awal pembelajaran siswa kurang tertarik, diskusi tidak bersemangat, siswa belum menunjukkan perasaan senang terhadap materi pelajaran. Perhatian siswa terhadap peenjelasan guru sangat rendah, karena guru belum menggunakan media yang tepat untuk menarik perhatian siswa. Hasil pengamatan minat belajar dapat dirangkum sebagai berikut:

Tabel 2

Hasil Pengamatan Minat Belajar (Prasiklus)

\begin{tabular}{|l|l|l|l|l|l|l|l|}
\hline \multirow{2}{*}{ No } & \multirow{2}{*}{ Responden } & \multicolumn{5}{|c|}{ Aspek } & \multirow{2}{*}{ Ket } \\
\cline { 3 - 7 } & & Ketertarikan & $\begin{array}{l}\text { Perasaan } \\
\text { Senang }\end{array}$ & Perhatian & Semangat & Rerata & \\
\hline 1 & 01 & $25 \%$ & $24 \%$ & $25 \%$ & $26 \%$ & $25 \%$ & kurang \\
\hline 2 & 02 & $23 \%$ & $24 \%$ & $25 \%$ & $22 \%$ & $23,2 \%$ & kurang \\
\hline 3 & 03 & $51 \%$ & $45 \%$ & $50 \%$ & $52 \%$ & $49,5 \%$ & sedang \\
\hline 4 & 04 & $25 \%$ & $25 \%$ & $25 \%$ & $23 \%$ & $24,2 \%$ & kurang \\
\hline
\end{tabular}

Paling tidak minat belajar anak mencapai kategori cukup yakni sekitar 51 Kriteria pencapaian aspek minat sebagai berikut:

Kurang $0-25 \%$

Sedang $26 \%-50 \%$

Cukup $51 \%-75 \%$

Tinggi $75 \%-100 \%$

Dari table tersebut di atas dapat dilihat bahwa $25 \%$ siswa yakni 1 orang siswa dari 4 siswa memiliki minat belajar yang sedang. Tujuh puluh lima (75) persen yang lain yakni 3 orang siswa dari 4 siswa minat belajarnya masih kurang. Hal inilah menjadi tantangan bagi guru untuk meningkatkan minat belajar siswa $75 \%$.

3. Hasil Belajar

Rendahnya minat belajar siswa mempengaruhi hasil belajar pada prasiklus. Hal ini bisa dilihat dari 4 siswa ada 3 siswa yang mendapat nilai dibawah KKM sedangkan 1 siswa telah mencapai KKM. Hal tersebut bisa dilihat pada table berikut:

Tabel 3

Rekap Hasil Belajar Prasiklus

\begin{tabular}{|l|l|l|l|l|}
\hline No. & Responden & Nilai & Tuntas & Belum Tuntas \\
\hline 1. & Responden 01 & 60 & - & V \\
\hline 2. & Responden 02 & 30 & - & V \\
\hline 3. & Responden 03 & 70 & V & - \\
\hline
\end{tabular}




\begin{tabular}{|l|l|l|l|l|}
\hline 4. & Responden 04 & 10 & - & V \\
\hline
\end{tabular}

Hasil Penelitian Siklus I

1. Proses Pembelajaran

Berdasarkan pengamatan peneliti, proses pembelajaran pada siklus I mulai menunjukkan peningkatan. Pada siklus I ini, peneliti mulai menerapkan strategi pembelajaran tipe AIR (actualy, intelectualy, repetition). Peneliti mengkolaborasikan strategi pembelajaran dengan media kartu sejarah.

Berdasarkan pengamatan pada pembelajaran siklus I difokuskan pada penilaian proses yang meliputi 3 indikator yaitu : a) aktif atau tidaknya siswa dalam mengikuti proses pembelajaran mengenal sejarah peninggalan masa Hindu, Budha, dan islam di Indonesia. b) antusias atau tidaknya siswa dalam mengikuti proses pembelajaran, c) kondusif atau tidaknya siswa dalam pembelajaran. Pada indicator a) Tingkat keaktifan siswa pada siklus I diperoleh data bahwa jumlah siswa yang aktif dalam proses pembelajaran adalah 2 siswa dari 4 siswa atau sebanyak $50 \%$. Sebanyak 2 siswa atau 50\% siswa belum aktif mengikuti pembelajaran. Diperoleh informasi dari siswa mereka belum paham cara menggunakan media kartu sejarah. Pada indicator b) antusias tidaknya siswa dalam mengikuti proses pembelajaran. Siswa mulai menampakkan sikap antusias pada pembelajaran. Ada 3 siswa yang antusias, sedangkan 1 siswa belum menunjukkan sikap antusias. Ditemukan kondisi siswa yang belum antusias karena siswa tersebut belum lancar membaca dan merasa bingung. Hal ini dibuktikan ketika responden diwawancarai. Pada indicator c)pada indicator kondusif atau tidaknya siswa, pada siklus I ini diperoleh data bahwa: jumlah siswa yang berperan serta dalam proses pembelajaran adalah 3 siswa dari 4 siswa atau $75 \%$, sebanyak $25 \%$ siswa belum kondusif dalam proses pembelajaran. Siswa yang belum berperan serta disebabkan karena ada siswa yang cenderung mengandalkan jawaban dari temannya. Siswa tersebut hanya diam menunggu jawaban temannya.

Pada akhir siklus I dilakukan wawancara dengan 2 orang responden dan dilakukan secara terpisah. Dari hasil pengamatan dan wawancara, proses pembelajaran pada siklus I ada peningkatan tingkat keaktivan siswa. Penerapan strategi pembelajaran tipe AIR dalam pembelajaran IImu Pengetahuan Sosial (IPS) dengan pokok materi sejarah terlihat diminati sebagian siswa. Kenaikkan keaktifan siswa dari prasiklus yang aktif $25 \%$ menjadi $75 \%$.

2. Minat Belajar

Minat belajar siswa dapat dilihat dari: ketertarikan pada pelajaran, rasa senang mengikuti pembelajaran, memiliki perhatian, dan semangat mengikuti pembelajaran. Pada siklus I minat belajar siswa sedikit meningkat. Dua responden memiliki minat belajar sedang, 1 responden kurang, dan seorang lagi memiliki minat tinggi.

3. Hasil Belajar

Kemampuan menguasai materi peninggalan sejarah masa Hindu, Budha dan Islam pada kelas $\mathrm{V}$ lebih meningkat. Terbukti dua siswa telah tuntas sedangkan dua yang lainnya belum tuntas. Table 4 menunjukkan hal tersebut.

Table 4

Daftar Perolehan Nilai Hasil belajar Siklus I

\begin{tabular}{|l|l|l|l|l|}
\hline No. & Responden & Nilai & Tuntas & Belum Tuntas \\
\hline 1. & RESPONDEN 01 & 70 & V & - \\
\hline 2. & RESPONDEN 02 & 50 & - & V \\
\hline 3. & RESPONDEN 03 & 80 & V & - \\
\hline 4. & RESPONDEN 04 & 10 & - & V \\
\hline
\end{tabular}


Berdasar table di atas diambil kesimpulan bahwa 50\% siswa sudah tuntas, $50 \%$ belum tuntas. Setelah pembelajaran Siklus I yang terdiri 3 pertemuan berakhir, peneliti mengadakan musyawarah dengan kepala sekolah dan teman sejawat. Pembicaraan seputar proses pembelajaran yang berdasarkan pengamatan, catatan lapangan dan wawancara. Hasil belajar sudah mengalami peningkatan ari prasiklus ke siklus I, tetapi peningkatan belummemenuhi target dalam indicator kinerja. Dalam hal ini peneliti mendapat berbagai masukan untuk memperbaiki dan meningkatkan kualitas pembelajaran. Untuk itu penelitian dilanjutkan ke siklus II.

Hasil Penelitian Siklus II

1. Proses pembelajaran

Berdasarkan pengamatan pada pembelajaran siklus II, proses pembelajaran yang meliputi 3 indikator yaitu keaktifan, antusias, dan kondusif. Pada pembelajaran siklus II ini, peneliti masih menerapkan strategi pembelajaran tipe AIR dengan kolaborasi media kartu sejarah. Dari hasil pengamatan ditemukan siswa sudah aktif dan mulai bisa memanfaatkan media kartu tersebut. Indikator kinerja pada proses pembelajaran mengalami peningkatan. Siswa terlihat aktif dan antusias dalam pembelajaran.

2. Minat Belajar

Pada siklus II ini indicator minat mulai terpenuhi. Terlihat dalam pengamatan, siswa menjadi lebih tertarik pada materi pelajaran, siswa senang mengikuti,dan penuh perhatian. Siswa lebih semangat mengikuti pembelajaran.

3. Hasil belajar

Kemampuan menguasai materi pembelajaran pada siklus II mengalami peningkatan. Adapun hasil belajar pada siklus II seperti berikut :

Tabel 5

Daftar Nilai Siklus II

\begin{tabular}{|l|l|l|l|l|}
\hline No. & Responden & Nilai & Tuntas & Belum Tuntas \\
\hline 1. & Responden 01 & 80 & V & - \\
\hline 2. & Responden 02 & 90 & V & - \\
\hline 3. & Responden 03 & 90 & V & - \\
\hline 4. & Responden 04 & 20 & - & V \\
\hline
\end{tabular}

Berdasarkan perolehan pada table di atas anak yang telah mencapai KKM 75\%, sedangkan $25 \%$ belum mencapai KKM.

Pembahasan Hasil Penelitian :

1. Proses pembelajaran

Proses pembelajaran pada penelitian ini difokuskan pada proses untuk meningkatkan minat dan hsil belajar siswa. Data yang diperoleh dari perbandingan proses pembelajaran pada kondisi prasiklus, siklus I, dan siklus II. Proses pembelajaran yang diamati meliputi 3 faktor yaitu, keaktivan, antusias, dan kondusifnya dalam pembelajaran. Berikut disajikan perbandingan dalam proses pembelajaran secara keseluruhan:

Tabel 6

Data Perbandingan dalam Proses Pembelajaran Prasiklus, siklus I, dan siklus II

\begin{tabular}{|l|l|l|l|l|l|l|l|}
\hline \multirow{2}{*}{ No } & \multirow{3}{*}{ Indikator } & \multicolumn{3}{l}{ Prasiklus } & \multicolumn{2}{l|}{ Siklus I } & \multicolumn{2}{l|}{ Siklus II } \\
\cline { 3 - 8 } & & Ya & Tidak & Ya & Tidak & Ya & Tidak \\
\cline { 3 - 8 } & $\%$ & $\%$ & $\%$ & $\%$ & $\%$ & $\%$ \\
\hline 1. & Aktif & 25 & 75 & 75 & 25 & 100 & 0 \\
\hline 2. & Antusias & 25 & 75 & 75 & 25 & 100 & 0 \\
\hline 3. & Kondusif & 25 & 75 & 75 & 25 & 100 & 0 \\
\hline \multicolumn{2}{l}{ Rerata } & $\mathbf{2 5}$ & 75 & $\mathbf{7 5}$ & 25 & $\mathbf{1 0 0}$ & 0 \\
\hline
\end{tabular}




\begin{tabular}{|l|l|l|l|}
\hline Kategori & Kurang & Cukup & Baik \\
\hline
\end{tabular}

Tabel di atas adalah data perbandingan keaktifan siswa secara keseluruhan dalam proses pembelajaran Prasiklus, Siklus I, dan Siklus II. Pada indikator aktif siswa selama proses pembelajaran, terjadi peningkatan dari $25 \%$ pada Prasiklus meningkat menjadi $75 \%$ pada Siklus I, dan meningkat menjadi $100 \%$ pada Siklus II. Pada indikator antusias siswa selama proses pembelajaran, terjadi peningkatan dari $25 \%$ pada Prasiklus meningkat menjadi $75 \%$ pada Siklus I, dan meningkat menjadi $100 \%$ pada Siklus II. Pada indikator kondusif siswa selama proses pembelajaran, terjadi peningkatan dari $25 \%$ pada Prasiklus meningkat menjadi $75 \%$ pada Siklus I, dan meningkat menjadi $100 \%$ pada Siklus II. Proses pembelajaran dari Prasiklus ke Siklus I mengalami peningkatan sebesar $50 \%$ dari kategori Kurang menjadi kategori sedang. Dari Siklus I ke Siklus II terjadi peningkatan sebesar $25 \%$ dari kategori sedang menjadi kategori cukup. Secara keseluruhan proses pembelajaran mengalami peningkatan sebesar $75 \%$ dengan kategori dari Kurang Baik menjadi kategori cukup.

2. Hasil Wawancara dengan Siswa

Setelah pembelajaran Siklus I selesai, guru mengadakan wawancara dengan siswa untuk mengetahui dampak yang dirasakan siswa dari proses pembelajaran pada Siklus I. Wawancara dilakukan di dalam ruang kelas $V$ setelah pembelajaran Siklus I selesai. Wawancara berlangsung pada hari Selasa, 4 September 2018. Wawancara pertama adalah wawancara antara guru dengan siswa responden $02 \mathrm{i}$ dan wawancara kedua adalah wawancara guru dengan siswa responden 03.Adapun pelaksanaan wawancara dengan siswa pada Siklus II dilaksanakan hari Rabu, 19 September 2018. Wawancara pertama antara guru dengan siswa responden 01 dan wawancara yang kedua antara guru dengan siswa responden 04.Berdasarkan wawancara dengan siswa pada siklus I dan siklus II diperoleh kesimpulan bahwa pembelajaran dengan menerapkan strategi pembelajaran tipe AIR ( Auditory, Intellectualy, Repetition ) yang dikolaborasikan dengan penggunaan media kartu sejarah, terbukti bisa membuat siswa belajar lebih bergairah. Mereka tertantang dengan permasalahan yang ada pada tugas dengan berdiskusi kelompok. Siswa lebih mudah memahami materi dan bisa mengingatnya.

3. Minat Belajar

Pada penelitian ini aspek minat diamati secara khusus dan tersendiri. Data aspek-aspek minat diperoleh pada kondisi awal, siklus I dan, siklus II. Adapun aspek-aspek minat meliputi ketertarikan, perasaan senang, perhatian dan semangat.

Pada kondisi awal ketertarikan siswa terhadap materi dan pembelajaran banyak yang masih dalam kategori kurang. Ada 3 siswa dari 4 siswa atau $75 \%$ siswa belum memiliki ketertarikan. Sedangkan 1 siswa atau $25 \%$ sudah memiliki ketertarikan, tetapi kategori baru sedang. Kemudian pada siklus I terjadi peningkatan ketertarikan siswa menjadi 3 siswa atau $75 \%$. Dilanjut pada siklus II lebih meningkat lagi menjadi $100 \%$. Pada siklus I terjadi peningkatan katertarikan yakni 1 siswa dengan kategori tinggi dan 2 siswa dengan kategori sedang. Dan pada siklus II semakin meningkat lagi menjadi 4 siswa sudah mengalami ketertarikan terhadap materi dan pembelajaran. Tetapi dengan kategori yang berbeda. Dua siswa meningkat ke kategori tinggi. 1 siswa meningkat ke kategori cukup, dan seorang lagi meningkat ke kategori sedang.

Pada kondisi awal penelitian ini, perasaan senang siswa terhadap pembelajaran dengan materi peninggalan sejarah masa Hindu, Budha dan Islam di Indonesia masih kurang. KOndisi awal hanya 1 siswa atau $25 \%$. Itupun dalam kategori sedang. Pada siklus I meningkat menjadi 3 siswa atau $75 \%$ dengan 
kategori 2 siswa sedang dan 1 siswa tinggi. Kemudian pada siklus II perasaan senang siswa lebih meningkat lagi menjadi $100 \%$. Peningkatan ini dalam kategori yang berbeda, yakni 2 siswa dengan kategori tinggi, 1 siswa dengan kategori cukup, dan 1 siswa dengan kategori sedang.

Faktor minat berikutnya yaitu perhatian siswa terhadap materi dan penjelasan guru. Pada kondisi awal, perhatian siswa masih sangat kurang. Tiga siswa atau $75 \%$ perhatiannya sangat kurang. Sedangkan 1 siswa atau $25 \%$ sudah memiliki perhatian dengan kategori sedang. Pada siklus I terjadi peningkatan menjadi $75 \%$. Ada 3 siswa yang memiliki perhatian dengan kategori 1 siswa tinggi dan 2 siswa sedang. Sedangkan 1 siswa masih dengan kategori kurang

4. Hasil Belajar

Setelah perolehan data nilai hasil belajar siswa terkumpul dan dianalisis, maka ditemukan kondisi sebagaimana pada table berikut.

Tabel 7

Rekapitulasi Perolehan Nilai Hasil Belajar

\begin{tabular}{|l|l|l|l|l|}
\hline No & Responden & Prasiklus & Siklus I & Siklus li \\
\hline 1. & Responden 01 & 60 & 70 & 80 \\
\hline 2. & Responden 02 & 30 & 50 & 90 \\
\hline 3. & Responden 03 & 70 & 80 & 90 \\
\hline 4. & Responden 04 & 10 & 10 & 20 \\
\hline
\end{tabular}

Tabel di atas menunjukkan hasil belajar siswa sudah meningkat dari Prasiklus ke Siklus I kemudian ke Siklus II. Peningkatan ini ditunjukkan dengan persentase ketuntasan pada Prasiklus 25\%, pada Siklus I menjadi 50\% dan pada Siklus II menjadi $75 \%$. Pada interval nilai prestasi siswa dapat diuraikan sebagai berikut

Siswa dengan kategori nilai Sangat Baik (A) pada Prasiklus nol siswa karena siswa selama ini belum pernah menggunakan media kartu sejarah. Dalam pembelajaran hanya menggunakan buku paket. Siswa dengan kategori nilai Amat Baik (A) pada Siklus I ada 0 siswa. Siswa baru mencapai kategori nilai Baik. Meskipun siswa sudah mulai bisa dan terbiasa menggunakan media kartu sejarah. Siswa dengan kategori nilai Amat Baik (A) pada Siklus II juga tidak ada.

Siswa dengan kategori nilai Baik (B) pada Prasiklus ada 0 siswa karena belum semua siswa mampu menggunakan media kartu sejarah sebagai sarana untuk menginat materi pelajaran. Siswa dengan kategori nilai Baik (B) pada Siklus I ada 1 siswa. Siswa mulai mampu memanfaatkan media kartu sejarah untuk belajar dan memahami materi pelajaran. Siswa dengan kategori nilai Baik (B) pada siklus II ada 3 siswa. Siswa sudah mampu memanfaatkan media kartu sejarah untuk belajar dan memahami materi pelajaran.

Siswa dengan kategori nilai Cukup (C) pada Prasiklus ada 1 siswa. Hal ini dikarena mereka masih bingung menggunakan media kartu sejarah. Siswa dengan kategori nilai Cukup (C) pada Siklus I ada 1 siswa. Siswa mulai mampu menggunakan media kartu sejarah sebagai sarana belajar. Siswa dengan kategori nilai Cukup (C) pada Siklus II ada 0 siswa menggunakan media kartu sejarah sebagai sarana belajar. Siswa dengan kategori nilai kurang (D) pada Prasiklus masih banyak yaitu 3 siswa dari 4 siswa. Hal ini dikarenakan mereka belum mampu menggunakan media kartu sejarah sebagai sarana belajar. Siswa dengan kategori nilai kurang (D) pada Siklus I berkurang menjadi 2 siswa. Pada Siklus I ini siswa mulai mampu menggunakan media kartu sejarah sebagai sarana belajar. Siswa dengan kategori nilai kurang (D) pada Siklus II 
hanya tinggal 1 siswa. Anak ini belum mampu memanfaatkan media kartu sejarah sebagai sarana untuk mengingat dan memahami pelajaran

Berdasarkan uraian hasil belajar di atas,dapat disimpulkan bahwa terdapat peningkatan tiap indikator kinerja siswa baik pada proses maupun pada hasil belajar siswa dengan menerapkan strategi pembelajaran tipe AIR dalam pembelajaran dengan materi mengenal peninggalan - peninggalan sejarah masa Hindu, Budha dan Islam di Indonesia. Data menunjukkan pelaksanaan Siklus II telah mencapai target indikator kinerja yaitu proses pembelajaran minimal masuk dalam kategori Baik dan ketuntasan klasikal hasil belajar siswa mencapai $75 \%$ kategori Baik. Kenaikan rata-rata secara keseluruhan dari indikator kinerja tersebut menunjukkan kelebihan penerapan strategi pembelajaran tipe AIR. Terjadinya kenaikan rata-rata menunjukan jumlah siswa yang memahami materi mengalami peningkatan tiap siklusnya. Terlampauinya semua indikator kinerja menunjukan keberhasilan tindakan penelitian ini, oleh karena itu penelitian dihentikan sampai siklus II ini.

Penelitian ini sejalan dengan penelitian yang dilakukan oleh Irfi Hestu Nugraheni mahasiswa pada Fakultas Keguruan dan Ilmu Pendidikan, Universitas Sebelas Maret Surakarta. Skripsinya berjudul "Penerapan Model pembelajaran Kooperatif Tipe Auditory, Intellectually, Repetition (AIR) Untuk Meningkatkan KemampuanOperasi Hitung Campuran Bilangan Bulat". Penerapan model ini dilakukan pada siswa kelas IV SD Negeri Klaten tahun ajaran 2016/2017.

Pada penelitian ini disampaikan bahwa nilai rata-rata pratindakan memperoleh 58,30. Pada siklus I memperoleh nilai rata-rata 65,25. Kemudian pada siklus II meningkat menjadi 78,35. Untuk ketuntasan, pada pratindakan tuntas $31,03 \%$. Pada siklus I tuntas 68,97 \%. Siklus II 85,71\%. Kemudian diambil simpulan bahwa penggunaan model pembelajaran kooperatif tipe Auditory, Intellectually, Repetition (AIR) dengan didukung media kartu domino dapat meningkatkan kemampuan operasi hitung campuran bilangan bulat pada siswa kelas IV SD Negeri Klaten.

Penelitian yang sama juga dilakukan oleh sekelompok mahasiswa Universitas Riau. Mereka adalah Dina Putri Hasyim, Otang Kurniawan, dan Hendri Marhadi. Judul penelitiannya adalah " The Auditory, Intellectually, repetition (AIR) Implementation To Improve learning Outcomes Student At IPS in Fuorth Graderes SDN 032 Kualu. Dalam penelitian tersebut disampaikan bahwa KKM mata pelajaran IPS 70. Siswa yang mencapai KKM hanya $40 \%$ dari 35 anak yaitu 14 anak saja. Yang berarti ada $60 \%$ yang bisa mencapai KKM yaitu 21 anak. Kemudian diterapkan model pembelajaran kooperatif tipe AIR menghasilkan Siklus I pada pertemuan I $83.3 \%$, pertemuan II menjadi 87,5\%. Dilanjutkan pada Siklus II, pertemuan I 91,6\%, dan pada pertemuan II 95,8 \%, yang berarti sangat bagus. Prosentasi keaktifan siswa pada pertemuan I $79,1 \%$, pertemuan II $83,3 \%$ pada siklus yang I. Pada siklus II pertemuan $187,5 \%$, pertemuan 2 menjadi $91,6 \%$. Nilai rata-rata pada pratindakan 64 menjadi 74,3 pada siklus I dan nilai rata-rata 91,2 pada siklus II.

\section{SIMPULAN}

Penelitian ini dapat ditarik simpulan bahwa:

1) Proses pembelajaran dengan menerapkan strategi pembelajaran tipe AIR ( Auditory, Intellectualy, and Repetition )berjalan lancar sesuai dengan RPP yang telah disusun, lebih efektif, aktif dan menyenangkan. Pembelajaran menjadi student centered bukan teacher centered dengan hasil belajar meningkat dari kategori kurang menjadi kategori baik.

2) Terdapat peningkatan minat belajar tentang peninggalan-peninggalan sejarah masa Hindu, Budha dan Islam di Indonesia pada siswa kelas V SDN 3 Mlopoharjo, Wuryantoro, tahun pelajaran 2018/2019. Peningkatan ini ditunjukkan dengan persentase minat belajar siswa dalam proses pembelajaran 
pada prasiklus hanya $25 \%$, pada Siklus I menjadi $75 \%$ dan pada siklus II meningkat menjadi $100 \%$.

3) Terdapat peningkatan hasil belajar tentang peninggalan - peninggalan sejarah masa Hindu, Budha dan Islam di Indonesia pada siswa kelas V SDN 3 Mlopoharjo, Wuryantoro, tahun pelajaran 2018/2019 setela menggunakan strategi pembelajaran kooperatif tipe AIR ( Auditory, Intellectualy, and Repetition ). Peningkatan ini ditunjukkan dengan persentase ketuntasan pada prasiklus hanya $25 \%$, pada Siklus I menjadi $50 \%$ dan pada siklus II meningkat menjadi $75 \%$.

\section{DAFTAR PUSTAKA}

Subyantoro. 2017. PTK Penelitian Tindakan Kelas. Semarang:Farishma Indonesia.

Suwandi, Sarwiji. 2008. Penelitian Tindakan Kelas, dan Penulisan Karya IImiah Modul $P L P G$. Surakarta:FKIP UNS.

Baharuddin dan Esa Nur Wahyuni, 2009. Teori Belajar dan Pembelajaran, Jogjakarta:Ar-Ruzz Media.

Fajri, Em Zul dan Ratu Aprilia Senja. 2005. Kamus Lengkap Bahasa Indonesia. Jakarta: Difa Publisher.

Rosdijati, Nani, zainal Aib dan Trimo, 2010. Panduan Pakem IPS SD Mengajar IPS dengan Aktif, Kreatif, Efektif dan Menyenangkan. Jakarta:Erlangga.

Slameto. 2010. Belajar dan Faktor yang Mempengaruhinya. Jakarta:Rineka Cipta

Arikunto, Suharsimi,1993.Prosedur Penelitian. Jakarta:Rineka Cipta

Muhtarom, 2012. Penerapan Model AIR(Auditory, Intellectualy, Repetition) dengan Strategi Peninjauan Kembali untuk Meningkatakan Kreativitas dan hasil Belajar Siswa di Madrasah Aliyah Nurul Ummah, Kota gede, Yogyakarta ( Sripsi).

Irfi Hestu Nugraheni, 2017. Penerapan Model Pembelajaran Kooperatif Tipe Auditory, Intellectualy, Repetition (AIR) Untuk Meningkatkan Kemampuan Operasi Hitung Campuran Bilangan Bulat pada Siswa Kelas IV SDNegeri Klaten Tahun Ajaran 2016/2017 (Skripsi).

Diana Putri Hasim,dkk. 2015. The Auditory, Intellectualy, and Repetition (AIR) Implemntation to Improve Learning Aotcomes Student at IPS in Fourth Graderes SDN 032 Kualu. (skripsi)

Suwandi, Sarwiji. 2010. Model Assesmen Dalam pembelajaran. Surakarta:Yuma Pustaka.

Asrori, Muhammad.2008. Psikologi Pembelajaran. Banduns:CV Wacana Prima. Https://www.google.co.id diunduh pada hari Jumat, 3 Agustus 2018 pukul 10.04 WIB Https://perpuskampus.com dinduh pada hari sabtu,4 Agustus 2018, pukul 10.00 